\title{
DIE BETEKENIS EN KONTEKS VAN GENADE EN WAARHEID IN JOHANNES 1:14-18
}

P P A KOTZÉ

\begin{abstract}
The meaning and context of "grace and truth" in John 1:14-18

The meaning of a word or phrase must be determined in its immediate context. This is a very sound hermeneutical principle, but it cannot be absolutised as will be pointed out in this article where the principle is applied to the concept "grace and truth" in John $1: 14-18$. As will become clear this phrase gathers the wealth of its meaning from outside the text itself. Only from its extra-textual context can the true meaning, which focuses on the faithfulness of God to His covenant, be appreciated.
\end{abstract}

Die woordgroep" "genade en waarheid" (charis kai aletheia) kom in die Johannesevangelie slegs in 1:14-18 voor waar dit 'n paar keer herhaal word. Daarna kom dit nie weer so saam voor nie. Die woord "waarheid" kom nog dikwels voor. " Maar die woord "genade" gebruik die skrywer nie weer nie, ook nie in sy ander geskrifte nie. ${ }^{3 \prime}$ Oor die rede vir hierdie eienaardige gebruik, kan maar slegs gespekuleer word."

So 'n herhaling in geïsoleerde gebruik, laat die vermoede ontstaan dat die skrywer iets besonders daarmee wou deurgee en dit is dus aktueel om hierdie iets besonders te probeer peil veral ook met die oog op die gebruik daarvan in die prediking.

In hierdie poging om oor die betekenis te besin, sal 'n literêr-kritiese benadering gevolg word waarin die struktuuranalise die vertrekpunt sal wees. So ' $n$ benadering stel as voorvereiste dat die betekenis primêr in teksverband bepaal sal word. Wat Johannes betref, moet die voorvereiste egter versigtig hanteer word. Dikwels oorskrei die teks self die grense van sy konteks deur verskillende verwysings na buite die teks in die lig waarvan woorde en begrippe in die teks eers hul regte betekenis kry. Dit is die bedoeling om die belangrikste sake waarna die teks in 1:14-18 verwys, te identifiseer en aan te toon hoe dit die verstaan van "genade en waarheid" bepaal. So 'n aanpak vereis dat die literêr-kritiese metode aangevul sal word met die histories-kritiese metode. Uit die aard van die saak kan nie al die verwysings aan die orde gestel word nie - slegs soveel as wat nodig is om hierdie doel te bereik. Die beweging sal dus plaasvind vanaf die teks na buite en weer terug na die teks. 


\section{Teksafbakening}

Joh 1:14-18 is deel van die proloog, maar vorm tog 'n relatief selfstandige betekeniseenheid met 'n definitiewe breuk in die gedagtegang tussen vers 13 en 14 . Vers 13 sê dat kinders van God uit Hom gebore word en nie anders nie. Vers 14 sê iets anders - dat die Logos mens geword het en hoe gelowiges Hom waargeneem en ervaar het. By vers 18 sluit die proloog af en by vers 19 begin die "historiese" deel van die evangelie.

\section{Struktuur}

Ondanks fynere verskille tussen geleerdes, veral wat terminologie betref, sou gesê kon word dat 'n groot aantal van hulle saamstem dat die proloog in een of ander vorm "chiasties" opgebou is. ${ }^{51}$

Verse 14-18 vertoon ook 'n chiastiese konstruksie met semantiese implikasies soos later aangetoon sal word. Die twee genoemde verse, die een aan die begin en die ander aan die einde van die subperikoop, vertoon duidelike betekenisooreenkomste:

(a) In albei word die Seun (Logos), enigste Seun genoem (monogenous in vers 14 en monogenes in vers 18).

(b) In albei word die verhouding van die Seun tot die Vader beskryf: in vers 14: "van die Vader" (para patros) en in vers 18: "wat die naaste aan die Vader is" of "wat in die boesem van die Vader is" (eis ton kolpon tou patros).

(c) In albei kom openbaring ter sprake: in vers 14: "ons het sy heerlikheid gesien", d.i. openbaring soos waargeneem; in vers 18: "Hy het Hom bekend gemaak".

Vers 15 en 17 toon ook verwantskap in die toespeling op die OuTestamentiese bedeling: In vers 15 staan die getuienis van Johannes die Doper wat homself later identifiseer: "Ek is die een wat in die woestyn roep: Maak die pad vir die Here reguit" (1: 23), 'n "aanhaling" uit Jesaja 40:3. Hieroor sê C K Barrett: "This comes near to saying that the Baptist is himself the voice of the Old Testament the witness to salvation" 14:22 cf. 5:46). ${ }^{6)}$ Vers 17 vermeld die Ou-Testamentiese figuur Moses en die wet.

Vers 16 vorm die wentelpunt van hierdie chiasme: 
"En uit sy volheid het ons almal ontvang genade op genade"

a) 14. $\quad$ 1. Die Woord het mens geword

en onder ons kom woon.

4. Ons het sy heerlikheid gesien,

$$
\left[\begin{array}{ll}
3.1 & \begin{array}{l}
\text { die heerlikheid wat } H y, \\
\text { as die enigste Seun, } \\
\text { van die Vader het, }
\end{array} \\
3.2 & \text { vol genade en waarheid. }
\end{array}\right.
$$

b) 15 . Johannes getuig van Hom en roep uit:

4.1 Dit is Hy wat ek bedoel het toe ek gesê het:

4.1.1 Hy wat na my kom,

4.1.2 is my voor,

- 4.1.3 want $\mathrm{Hy}$ was voor my reeds daar

c) 16

b1) 17

$a^{11}$

18.

$\left[\begin{array}{ll}\text { 8. } & \text { Niemand het God ooit gesien nie. } \\ \text { 9. } & \text { Sy enigste Seun, self God, }\end{array}\right.$

die genade en die waarheid het

deur Jesus Christus gekom.

wat in die boesem van die Vader is,

dié het Hom bekend gemaak.

\section{Gedagtegang}

Die heerlikheid van die mensgeworde Logos staan in direkte verband met sy verhouding tot die Vader want $\mathrm{Hy}$ straal heerlikheid uit as enigste Seun van die Vader. Die heerlikheid word beskryf as vol van genade en waarheid. Johannes die Doper getuig van die Logos se voorrang en dan word die woord "vol" (p/ères) opgeneem deur "volheid" (p/eromatos): uit sy volheid het gelowiges genade op genade ontvang en hierdie 
situasie word verklaar ("want" - hoti) deur 'n teenstelling van of vergelyking tussen Moses en die wet aan die een kant en Jesus Christus met genade en waarheid aan die ander kant en die besondere verhouding waarin die Seun met die Vader verkeer (in sy boesem).

\section{Struktuurmerkers}

Nie al die struktuurmerkers sal volledig bespreek word nie, slegs die wat direk betrekking het op die betekenis "genade en waarheid," naamlik Logos, onder ons kom woon (eskenōsen en hemin), heerlikheid (doksa), genade en waarheid (charitos kai aletheias), volheid (plèrō matos), genade op genade (charin anti charitos), die wet deur Moses gegee (nomos dia Moüseōs edothe), die genade en waarheid het deur Jesus Christus gekom Ihe charis kai he aletheia dia lessou Christou egenetol.

\section{Logos}

Die hele voorafgaande gedeelte van die proloog word as't ware gewy aan die Logos in sy teologiese, kosmologiese en soteriologiese verhoudings en funksies. Die Ou-Testamentiese agtergrond vir die gebruik van die Logos-begrip as christologiese titel word oor die algemeen aanvaar. Die aanvang van die Johannesevangelie verwys ons na die skeppingsverhaal in Genesis 1 (vgl. en arche waarmee albei boeke begin). En soos God in Genesis 1 gespreek het om die skepping in aansyn te roep, so sê Johannes 1:3 dat die Logos ("die spreke" van God) alles laat ontstaan het. Die funksies van die woord in die Ou Testament word deur die Logos in die Johannesevangelie vervul ${ }^{7}$, , sodat gesê kan word dat die Logos wat mens geword het die vergestalting is van die spreke van God. Veral by die profete kry die woord 'n hoogs gepersonifieerde karakter, terwyl die standvastigheid en betroubaarheid daarvan beklemtoon word (Jes. 9:7; 40:8; 55:11).

Logos as christologiese titel kom ook nog voor in 1 Johannes $1: 1$ en Openbaring 19:13: Soos later duidelik sal blyk, is die gebruik in Openbaring van belang: Sy Naam is die Logos van God. Dit is die Naam van Hom wat op die wit perd is "en Hy word genoem Getrou en Waaragtig" (19:11).

Die agtergrond vir die Logos-titel in Johannes is dus primêr in die Ou Testament te vind met 'n beklemtoning van die standvastigheid en ewigheid daarvan deur die profete. Johannes getuig van die menswording van hierdie Logos in terme van "genade en waarheid" en Openbaring verbind sy Logos-naam aan getrouheid en waaragtigheid. Dit sou skematies soos volg voorgestel kon word: 


\begin{tabular}{|c|c|c|c|}
\hline \multicolumn{2}{|c|}{ OU TESTAMENT } & \multicolumn{2}{|c|}{ NUWE TESTAMENT } \\
\hline & & Johannes & Openbaring \\
\hline $\begin{array}{l}\text { Spreke van God } \\
\text { funksioneel. }\end{array}$ & $\begin{array}{l}\text { In profete } \\
\text { gepersonifieer } \\
\text { en gekwalifiseer } \\
\text { as ewig en } \\
\text { standvastig. }\end{array}$ & $\begin{array}{l}\text { Persoon } \\
\text { vol van } \\
\text { genade en } \\
\text { waarheid. }\end{array}$ & $\begin{array}{l}\text { Oorwinnaar } \\
\text { getrou } \\
\text { en } \\
\text { waaragtig. }\end{array}$ \\
\hline
\end{tabular}

\section{"Hy het onder ons kom woon"}

Dit is ' $n$ vertaling van eskenōsen en hemin. Eskenōsen word ook in buite-Bybelse literatuur gebruik vir "woning maak" of "kom woon". ${ }^{\text {B) }}$ Hierdie hele gedeelte is egter so heg ingebed in Ou-Testamentiese verbande dat dit bykans onmoontlik is om te dink dat dit ' $n$ ander agtergrond as die Ou Testament sal hê. In die LXX kom skene 435 keer voor; 370 keer as vertaling van ohel, d.i. "tent". Die Hebreeuse woord mishkan, "woning," word ook dikwels met skene vertaal, waarskynlik as gevolg van die ooreenstemming tussen die medeklinkers van skene (skn) en shakan (skn). ${ }^{91}$

Die funksie van die tabernakel in Israel is bekend: "Dat Ek in hulle midde kan woon" (Eks. 25:8). Dit was 'n skene van samekoms (Eks. 27:21; 29:4; 33:7; Lev. 1:1; Num. 11:16; 12:24; Deut. 31:14; Jos. 18:1; 19:51; 1 Sam. 2:22; 1 Kon. 8:4; ens). M.a.w. ons het hier te doen met die plek waar die verbond van God met sy volk tot verwerkliking gekom het; die plek waar die verkondiging plaasgevind het: "Ek sal vir julle 'n God wees en julle moet vir my 'n volk wees" en die gemeenskap met God beoefen is. Vanaf die ark van die verbond in die Allerheiligste van die tabernakel het God deur middel van Moses met die volk gepraat (Num. 7:89; 17:1-11).

Nou is dit belangrik om daarop te let dat wanneer Israel misluk in die nakoming van die verbond, die profete die gelokaliseerde teenwoordigheid van God as ' $n$ belofte vir die toekoms as besonder indrukwekkend skilder: "Dan sal julle weet dat Ek die Here julle God is wat woon (kataskenoun) op Sion, my heilige berg ..." (Joël 3:17). 10) Met die oog op die terugkeer van die volk uit ballingskap, kondig Sagaria aan: "Jubel en wees bly, o dogter van Sion, want kyk, Ek kom in julle midde woon" (kataskenoun, 2:10). In die ideale tempel wat Esegiël beskryf, sal God vir ewig Sy woning onder sy volk maak (43:7).

Een van die oorheersende motiewe van die Johannesevangelie is die intieme gemeenskap tussen die Vader en die Seun en die gelowiges 
wat bewerk sal word deur die Gees (14: $2 v, 2 i, 17: 21-22)$. In antisipasie hierop wys die skrywer in 1:14b "in tabernakel-taal" daarop dat die menswording van die Woord die nuwe "plek" van die teenwoordigheid van God onder sy volk sal wees. Die verbondsgemeenskap van God met sy volk kry op hierdie wyse unieke gestalte in God wat self mens geword het. Die getrouheid van God aan sy verbond word op onvergelykbare wyse geillustreer. Die mislukking van die mens in sy verbondsverhouding met God, laat God geluk deur self mens te word, deur self onder mense te kom tent opslaan.

Soos in die geval met die Logos trek Openbaring die lyn deur: "Kyk die tabernakel van God is by die mense en Hy sal by hulle woon" /skenoseil. Skematies sou dit soos volg voorgestel kon word:

\begin{tabular}{|l|l|l|l|}
\hline \multicolumn{2}{|c|}{ OU TESTAMENT } & \multicolumn{2}{c|}{ NUWE TESTAMENT } \\
\hline (veral Eksodus) & Profete & Johannes & Openbaring \\
\hline Plek van ver- & Verbonds- & $\begin{array}{l}\text { Logos- } \\
\text { plek van } \\
\text { bondsgemeen- } \\
\text { skap. }\end{array}$ & $\begin{array}{l}\text { God se nuwe } \\
\text { Vooruitsig: } \\
\text { nuwe ge- } \\
\text { tabernakel } \\
\text { van God is by } \\
\text { die mense." }\end{array}$ \\
\hline
\end{tabular}

\section{"En ons het sy heerlikheid gesien"}

Die stelling dat die Woord "onder ons kom tabernakel het" word met 'n parataktiese kai opgevolg met: "En ons het sy heerlikheid gesien." Wat hierop volg is beskrywing en kwalifisering van die heerlikheid (doksa) van die Logos.

Doksa is die woord wat die $L X X$ verkies om die Ou-Testamentiese kabōd te verhaal. By die lees van Johannes 1:14 word nie altyd besef dat juis die spreke van God in die tabernakel gepaard gegaan het met die verskyning van sy heerlikheid nie. Toe die tabernakel voltooi is "toe het die wolk die tent van samekoms (ohel) oordek en die heerlikheid (kabōd) van die Here het die tabernakel (mishkan) vervul" (Eks. 40:34). Dieselfde het gebeur by die inwyding van die tempel (1 Kon. 8:10-11). Voor die verwoesting van die tempel deur die Babiloniërs het die heerlikheid van die Here die stad verlaat (Eseg. 11:23). Maar in Esegiël se visioen van die herstelde tempel, het die heerlikheid van die Here weer die tempel vervul (Eseg. 44:4). 
Hierdie Ou-Testamentiese agtergrond gee sin aan Johannes 1:14. Die Logos is die topos waar God in sy heerlikheid onder Sy volk kom woon het. In die Logos het sy heerlikheid "sigbaar" geword. Dit word onderstreep by geleentheid van die tempelreiniging waar geleer word dat Jesus die tempel vervang en dit geskied weer deur sy verheerliking aan die kruis en in sy opstanding. In Hom word Gods verbondsgemeenskap met sy volk ten volle verwesenlik. Net soos die woning van God onder sy volk in eskatologiese perspektief geplaas word (Op. 21:31, so ook sy heerlikheid maar nou beklemtoon deur simboliek: "En ek het gesien iets soos 'n see van glas, gemeng met vuur ... En hulle het die lied gesing van Moses ... Wie sal u Naam nie verheerlik nie? ... kyk, die tent van getuienis is geopen $(O p .15: 2,3,5)$.

Weer eens sou dit skematies soos volg voorgestel kon word:

\begin{tabular}{|l|l|l|l|}
\hline \multicolumn{2}{|c|}{ OU TESTAMENT } & \multicolumn{2}{c|}{ NUWE TESTAMENT } \\
\hline $\begin{array}{l}\text { Eksodus } \\
\text { 1 Konings }\end{array}$ & Profete & Johannes & Openbaring \\
\hline $\begin{array}{l}\text { Kabö by die } \\
\text { gemeenskap } \\
\text { van God met } \\
\text { sy volk. }\end{array}$ & $\begin{array}{l}\text { Verbonds- } \\
\text { versaking - } \\
\text { heerlikheid } \\
\text { wyk. Voor- } \\
\text { uitsig op } \\
\text { herstelde } \\
\text { heerlikheid. }\end{array}$ & $\begin{array}{l}\text { Ooggetuies } \\
\text { "sien" die } \\
\text { doksa van } \\
\text { God in die } \\
\text { mensgeworde } \\
\text { Logos. }\end{array}$ & $\begin{array}{l}\text { Konsummasie } \\
\text { van sien van } \\
\text { die heerlik- } \\
\text { heid van God. }\end{array}$ \\
\hline
\end{tabular}

\section{Vol van genade en waarheid}

Die heerlikheid van die Logos word beskryf as "vol van genade en waarheid". Pleres ("vol") word geneem as onverbuigde vorm"1) wat die kwaliteit van doksa beskryf.

Dit word redelik algemeen aanvaar dat ons in die kombinasie "genade en waarheid" (charitos kai aletheia) 'n verwysing het na die OuTestamentiese chesed we'emet, 12) ("guns en trou, of goedheid en trou"). Dit is egter opmerklik dat die LXX (chesed meestal met eleos vertaal (Gen. 24:49; 2 Sam. 2:6; Jos. 2:14; Ps. 25:10; 85:11; 89:15; Spr. 14:22, om maar 'n paar plekke te noem) of eleemosune (Spr. $3: 3 ; 16: 6$ ) of polueleos (Eks. 34:6). Daar is egter aanduidings dat in die latere stadia van die $L X X$ dat charis bo eleos verkies is as vertaling van chesed $^{13)}$ soos byvoorbeeld in Ester 2:9 en die vertaling van Symmachus van 2 Sam. 
2:6; 10:2; Ps. 30:8; 39:11; 88:25 en die Quinta ook in Ps. $32: 5$ en die Sexta in Ps. $30: 17 ; 32: 18 .^{14}$

Hierdie verandering kan saamhang met ' $n$ verandering van die aard van die verbondsverhouding van God met sy volk. G. Farr ${ }^{15}$ ) kom in sy studie oor genade in Hosea tot die gevolgtrekking dat hoewel die LXX chesed in Hosea met eleos vertaal dit reeds die betekenis van charis verkry. As die verbondskending aan die kant van die volk sy laagwatermerk verkry soos in die huweliksgeskiedenis van Hosea gesimboliseer, verander die verbonds-chesed en emet (liefde en trou) van God nie. Dan verdiep die genadekarakter van die verbond juis. "Paul is only christianising the message of Hosea". In die Deuteronomiese skool is chesed volgens Farr beperk tot "provision for a just reward for righteous living". By Hosea is dit anders. "Here, if justice and mercy contradict each other, mercy glorieth against judgment" (James 2:13). W. Eichrodt druk dieselfde gedagte anders uit as hy van die genadekarakter van die verbond in Hosea praat as "die irrationele Macht der Liebe als tiefste Grund des Bundesverhältnis"16) en N.H. Snaith nog anders as hy sê: "We get here the beginning of a development which reaches its climax in the New Testament charis (grace), that undeserved, unmerited favour. "17) Dit is dus heeltemal verstaanbaar dat Johannes charis in plaas van eleos gebruik.

Die betekenis van die begrip "waarhejd" moet vanuit hierdie oorwegings verstaan word. Drie en twintig uit die drie en veertig gevalle waar chesed (goedheid) deur middel van 'n waw-copulativum met 'n ander naamwoord verbind word, geskied dit ten opsigte van emet ("trou") of emuna. ${ }^{18)}$ Die verbinding word oor die algemeen beskou as hendiadys ${ }^{19)}$ of dat emet en emuna die funksie van beskrywende byvoeglike naamwoorde ten opsigte van chesed vervul. Die samehang van die twee begrippe word bevestig deur die herhaalde ${ }^{201}$ gebruik daarvan in parallelismus membrorum soos byvoorbeeld in Jesaja 16:5, Miga 7:20 en Psalm 26:3 onderskeidelik:211

"En opgerig is deur chesed (goedgunstigheid) 'n troon, en daarop sit een in emet (getrouheid) in Dawid se tent" ${ }^{\prime 22}$ )

"U sal emet (trou) bewys aan Jakob, chesed (goedheid) aan Abraham."

"Want u chesed (goedheid) is voor my oë, Ek lewe deur u emet (trou)".

Nou is dit opvallend dat meer as $80 \%$ van die gebruike van emet en 
emuna in verband met die verbond staan, trouens in Jesaja 55:3 word die verbond as't ware gedefinieer in terme van "die bestendige genadebewyse van Dawid".

Die getrouheid van God word op indrukwekkende wyse bevestig deur sy eed. In die verband word byvoorbeeld in die Psalms verskillende motiewe saamgetrek: Die verbond, die messiaanse koning, die chesed (goedheid) en emet (trou) van God en God se eed:

"Ek sal altyd sing van die Here se liefdesdade (chasde), sy trou (emunateka) verkondig met my mond van geslag tot geslag. Want ek het gesê: goedheid (chesed) sal vir altyd gebou word; in die hemele - daar bevestig $U$ u trou (emunateka).

Ek het ' $n$ verbond gesluit met my uitverkorene, met ' $n$ eed aan Dawid, my kneg belowe ..." (Ps 89:2-4). ${ }^{23}$ )

Wanneer die volk die verbond verbreek soos in Jeremia 5:1vv beskrywe word, word hulle herinner aan die eed wat God gesweer het.

Wanneer Johannes nou hierdie tegniese verbondsterme, "vol van genade en waarheid" (pleres charitos kai aletheia), gebruik in 'n konteks waarin daar soveel verwysings na die verbond is, dan kan met 'n mate van oortuiging gesê word dat ons hier ' $n$ weerklank vind van Eksodus 34:6: "Here, Here ... groot van goedheid en trou" (rab chesed we'emet).

Die implikasie van hierdie bevinding is dat aan "waarheid" nie slegs 'n filosofiese definisie van: dit wat met die werklikheid ooreenkom, gegee kan word nie. Dit sal ook 'n konnotasie van waaragtigheid en trou inhou. Juis die konsummasie van God se liefde en trou, die toppunt daarvan, kry gestalte in die Woord wat vlees geword het. Sou 'n mens hierdie konsummasie of toppunt wou interpreteer in terme van waarheid, filosofies gedefinieer as dit wat ooreenstem met die werklikheid, sou dit aanvaarbaar kan wees. $H$. Schlier wil die dubbele betekeniskonnotasie plaas op rekening van die verskil tussen Griekse en Joodse denkwyse: " A $\lambda \eta \theta \in l a$ aber ist im Johannesevangelium, das die griechische und hebraische Grundbedeutung $\mathrm{zu}$ einer neue einheit eint, formal gesprochen das Unverborgene und Feststehende als Gerechte und Gultige." 24) Dit is 'n veralgemening wat James Barr hartlik bevraagteken het $^{25}$. Dat die verskil bestaan, word nie ontken nie, maar dit moet dan uit die bepaalde konteks duidelik blyk. In Johannes 1:14-18 het ons egter so 'n dubbele betekenisaksent. Dit word bevestig wanneer die verband deurgetrek word na Openbaring 19:11-13 waar die oorwinnaar, Christus, bekendgestel word as die Logos van God en dat Hy genoem word "getroue" (Pistos) en "waaragtige" (Alethinos).

Hierdie verbande sou soos volg voorgestel kon word: 


\begin{tabular}{|l|l|l|l|}
\hline \multicolumn{2}{|c|}{ OU TESTAMENT } & \multicolumn{2}{c|}{ NUWE TESTAMENT } \\
\hline Eksodus & $\begin{array}{l}\text { Psalms en } \\
\text { Profete }\end{array}$ & Johannes & Openbaring \\
\hline $\begin{array}{l}\text { Jahwe, groot } \\
\text { van goedheid } \\
\text { en trou. }\end{array}$ & $\begin{array}{l}\text { Trou van } \\
\text { God aan sy } \\
\text { verbond met } \\
\text { 'n eed } \\
\text { bevestig. }\end{array}$ & $\begin{array}{l}\text { Die heer- } \\
\text { likheid van } \\
\text { die Logos } \\
\text { vol van } \\
\text { genade en } \\
\text { waarheid. }\end{array}$ & $\begin{array}{l}\text { Die Oorwin- } \\
\text { naar se naam } \\
\text { is Logos en } \\
\text { word genoem: } \\
\text { die "getroue" } \\
\text { en "waaragtige." }\end{array}$ \\
\hline
\end{tabular}

\section{Genade op genade}

Die betekenis van "genade op genade" (charin anti charitos) hang m.i. nou saam met die verbande in die struktuur wat hierbo uiteengesit is. In vers 14 beskryf "genade en waarheid" die heerlikheid van die mensgeworde Logos. Dan volg die getuienis van Johannes die Doper waarin hy homself in rangorde laer stel as die Logos. Sy getuienis word opgevolg met die getuienis van die "skrywer" (cum suis):26) "En uit sy volheid het ons almal ontvang genade op genade" (kai charin anti charitos). Die betekenis van hierdie laaste woorde hang saam met die getuienis van Johannes die Doper oor die verskil in rangorde tussen homself en die Logos. Vers 17 hou dieselfde soort van "vergelyking" in tussen die wet wat deur Moses gegee is en die genade en waarheid wat deur Jesus Christus gekom het.

Laat ons hierdie struktuur voorlopig soos volg voorstel:

Vers 15

Vergelyking van rangorde

\section{Vers 17}

Vergelyking van rangorde

\section{Vers 16 \\ Funksionering van rangorde}

Om te verduidelik wat met die formulering "funksionering van rangorde" bedoel word, gee ons eers aandag aan vers 17.

Die eerste neiging is om in hierdie verklaring ' $n$ teenstelling te lees: Moses staan teenoor Christus en die wet staan teenoor die genade en die waarheid. Dat Johannes dit so antiteties bedoel het, kan nie sonder meer gesê word nie. Daar moet immers onderskei word tussen die Joodse 
legalisme soos deur Jesus en Paulus bestry en die wet as uitdrukking van God se wil wat beskryf word in terme van goedheid, lankmoedigheid, barmhartigheid, geregtigheid, liefde en trou. Die obligasiekarakter van die wet was uitvloeisel van die grasiekarakter daarvan. ${ }^{271}$ Geregtigheid word trouens beskryf in terme van genade (Ps. 51:16; 143:1-2; Sag. 9:9; Joël 2:23; Ps. 85:10-11) ${ }^{281}$. Johannes gebruik die woord "wet" (nomos), byvoorbeeld om die Skrif as bron van openbaring te beskryf: "Ons het Hom gevind van wie Moses in die wet en ook die profete geskrywe het." (Joh. 1:46). ${ }^{29)}$

Ook tussen Moses en Christus sien Johannes nie 'n ongenuanseerde teenstelling nie. Uit 6:14 is dit duidelik dat daar ' $n$ populêre opvatting onder die skare kon geheers het dat die koms van die Messias die vervulling was van die profeet soos in Deuteronomium 18:15 in die vooruitsig gestel is. Die verhoging van die slang deur Moses in die woestyn word deur Jesus self as tipies van sy eie verhoging gesien (Joh. $3: 14$ ) en die manna wat gegee is onder Moses se leierskap word verstaan as tipe van die brood uit die hemel. In die lig van hierdie gegewens is dit dus verstaanbaar dat $J$ Jeremias ${ }^{30}$ ' in hierdie gedeelte ook ' $n$ parallelisme vind. Hy werk dit wel nie in besonderhede uit nie maar sy bevinding dat ons hier met 'n sintetiese (en nie antitetiese parallelisme nie) te doen het, kan onderskryf word. In hierdie verband is dit tog betekenisvol dat daar nie 'n teenstellende men... de in die vers voorkom nie.

Hierbo is vir die formulering "funksionering van die rangorde" 'n verduideliking in die vooruitsig gestel. Die woorde "genade op genade" (kai charin anti charitos) beskryf die wyse waarop die gelowige uit die volheid van die Logos ontvang. As ons aanvaar dat Johannes die Doper bedoel het om deur sy getuienis ' $n$ rangorde tussen hom en Christus aan te dui en as ons verder aanvaar dat die vergelyking tussen die wet wat deur Moses gegee is en die genade en waarheid wat deur Jesus Christus gekom het ook as "'n soort van rangorde" in die genade van God beskryf (as 'n mens van so iets kan praat) dan beskryf "genade op genade" juis die aard van "die stroom" van hierdie genade. Die eerste "genade" word dan verteenwoordig deur die wet soos God dit deur Moses gegee het en die tweede "genade" word verteenwoordig deur die "genade en waarheid" wat deur Jesus Christus gekom het. Die tweede genade het gekom in die plek (anti) van die eerste; nie as teenstelling daarvan nie maar as konsummasie daarvan. Hierdie betekenis pas Johannes se gedagtegang as hy Jesus voorstel as die Een wat gekom het om die OuTestamentiese bedeling tot sy volle konsekwensie te voer soos vereis deur die verbondsgoedheid en -trou (chesed we'emet) van Jahwe of soos vereis deur die "genade en waarheid" van die Vader en geopenbaar in die Logos wat mens geword het. 


\section{Gevolgtrekkings}

1. Indien die verklaring van Johannes 1:14-18 slegs sou konsentreer op die onmiddellike tekstuele konteks sal dit neerkom op ' $n$ aansienlike betekenisreduksie. Dit wat in die proloog gesê word oor byvoorbeeld die Logos is geweldig baie; maar hoe wen hierdie "baie" nie aan betekenis nie as in ag geneem word dat die Logos inderdaad die eindpunt en suksespunt is van die spreke van God, herskeppend aan die gemeenskap wat misluk het as gevolg van die sonde van die kroon van sy skepping, die mens; dat $\mathrm{Hy}$ die bedoeling van die tabernakel verwesenlik en inderdaad die tempel vervang.

Om slegs 'n algemene betekenis aan die begrip "heerlikheid" te heg, sou vaag wees en sou dan ook, soos onlangs gebeur het, as "die mooiheid van God" verstaan kan word, want sy betekenismerkers sê alleen dat dit die heerlikheid is van die Logos wat $\mathrm{Hy}$ as enigste Seun van die Vader het, met ander woorde, dit is van goddelike oorsprong en kenmerk die Logos as enigste Seun van die Vader. Dit is verder "vol van genade en waarheid". Dit is moeilik om uit die konteks die betekenis van die woord "genade" te bepaal, veral aangesien dit nêrens weer in Johannes voorkom nie. Het dit 'n algemene betekenis van "onverdiende gawe"? "Waarheid" kom dikwels in Johannes voor in verskillende betekenisskakerings. ${ }^{31}$ ) Watter betekenis moet hier geld? Om dus die betekenis van die begrip "heerlikheid" op grond van hierdie betekenismerkers te bepaal, gee ' $n$ verskraalde betekenis. Dit verwys egter na die sigbare teenwoordigheid van God daar waar Hy saam met die mens kom woon. Die mensgeworde Logos is sy heerlikheid, sy sigbare teenwoordigheid in gemeenskap met die mens. Dit gaan gepaard met sy verbondsgoedheid of verbondsliefde en trou. Hy het immers sy trou aan die verbond met 'n eed bevestig. Met "genade en waarheid" wil Johannes die suksespunt van hierdie liefde en trou verwoord. Dit kan nie beter of verder nie. Dit is dan ook finale werklikheid (waarheid?).

Wat moet verstaan word onder "sy volheid"? Waarin bestaan dit konkreet? God se volheid is seker ewe moeilik om te verwoord as God self, maar iets daarvan word tog beskryf deur die "vol liefde en trou" van Eksodus 34:6. Die "volheid" bied "genade" in die plek van genade. Met erkenning van die moontlikheid van ' $n$ verskil in opvatting hieroor, bied die volgende voorstelling ' $n$ ewe moontlike verstaan wat bietjie meer gevul is met inhoud: (Kyk voorstelling op bladsy 50)

2. Dit is ten minste duidelik - en dit is ' $n$ onderbeklemtoning - dat Johannes van die Ou Testament gebruik gemaak het; meer as wat oor die algemeen erken word. Die wyse waarop hy dit gedoen het is van wesenlike belang. Vergelykenderwys het Johannes minder direkte aanhalings uit 


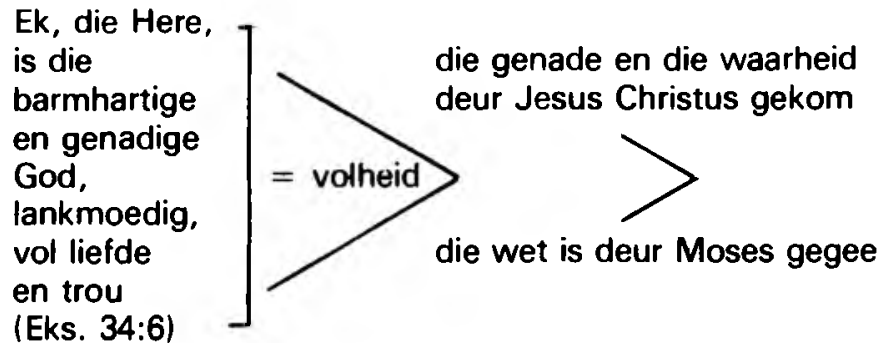

genade

op

genade

die Ou Testament as die Sinoptiese Evangelies. Sodra die leser egter besef op watter subtiele wyses die skrywer deur middel van sy woordgebruik, die kombinasie van woorde, toespelings, ens. na die Ou Testament verwys, kom hy tot die gevolgtrekking dat die skrywer geleef het in 'n Ou-Testamentiese denkklimaat en die Christusgebeure hieruit geïnterpreteer het al het hy nie van soveel direkte aanhalings gebruik gemaak nie. ${ }^{32)}$

\section{NOTAS}

1. In hendiadisvorm. Vergelyk R. Bultmann. Das Evangelium des Johannes, Göttingen, 1968, 49.

2. Met sy afgeleide en verwante vorme kom dit nog 55 keer voor: W F Moulton, As Geden en H K Moulton, A Concordance to the Greek New Testament, Edinburgh 1978, 5.

3. Behalwe Openbaring (as aanvaar word dat die apostel Johannes die outeur is) waar dit in die seënformule gebruik word (1:4 en 22:21).

4. Volgens Schnakenburg, "Das Johannesevangelium 1" in Herders theologischer Kommentar zum Neuen Testament, Freiburg, 1965, 246, word "genade" verder deur "Gees" en "lewe" verwoord. R A Culpepper, "The pivot of John's Prologue", NTS 27, 1981, 1-31, wil "lewe" laat korrespondeer met "genade" en J N Sanders, "The Gospel according to St John" in Black's New Testament Commentaries, London 1968, 82, sê weer: dit is ' $n$ tipiese Pauliniese term wat Johannes daarom vermy. L J Kuyper, "Grace and truth, an Old Testament description of God and its use in the Johannine Gospel," Interpretation XVIII, No 1 (Jan. 1964), 14, se mening is: "The full import of the concept within the expression grace and truth."

5. Die woord "chiasties" word tussen aanhalingstekens gebruik om te sê dat ruimte gelaat word vir verskille en veral vir die standpunt waarmee ek saamstem dat 'n chiastiese patroon nie rigied met detail-ooreenstemming op die teks afgedwing moet word soos Culpepper (a.w. ) dit wil doen nie. Johannes leen hom net nie daartoe nie. Dit is egter opmerklik hoe diegene wat 'n chiastiese opbou afwys, tog ook tot 'n soort van chiasme kom. C H Giblin, "Two complementary literary structures in John 1:1-18', JBL 104, 87-103, erken byoorbeeld implisiete chiasme in sy voorstel van komplimentêre strukture. Vergelyk ook $P$ Borgen, "The Logos was the true light" NT 14, 1972, 115-80; M. Hooker, "John the Baptist and the Johannine prologue", NTS XVI, 1669-70, 357 en Peter F Ellis, 1974, The Genius of John, A Composition-Critical Commentary on the Fourth Gospel, Minnesota, 1984, 27. 
6. New Testament Essays.

7. Die skepping deur die woord, Gen. 1; die openbaring deur die woord, Deut. 30:14; sending om te genees en te red, Ps. 107:20; Jes. 55:3, 11; as lig en lewe, Deut. 32:47; Ps. 119:8, 105, 130. Vergelyk ook F F Bruce. New Testament deve/opment of O/d Testament Themes, Michigan, 1968, 19.

8. R Bultmann, Das Evangelium des Johannes, Göttingen 1968, 43v.; W. Michaelis "Skenopegia", TWNT VII, 385.

9. Michaelis, a.w., 371.

10. Joël gebruik hier ook die ego-eimi-formule wat Johannes so dikwels gebruik.

11. F Blass, A Debrunner en F Rehkopf, Grammatik des neutestament/ichen Griechisch, Göttingen 1976, 137.

12. R. Schnackenburg, Das Johannesevangelium, Freiburg 1965, 272; C H Dodd, The interpretation of the Fourth Gospel, Cambridge, 8ste druk, 172; C K Barrett, The Gospel according to St John, 139; J H Bernard, A critical and exegetical commentary on the Gospel according to St John, ICC, Edinburgh, '1963, 27; R.E. Brown The Gospel according to St John,. New York, 1966.

13. C H Dodd, a.w., 175, R Schnackenburg, a.w. 272.

14. R Schnackenburg, a.w., 272.

15. "The Concept of Faith in the book of Hosea", Zeitschrift für die Alttestamentliche Wissenschaft, 70 (1958), 98-107.

16. Theologie des Alten Testaments 1, 1953, 127.

17. Mercy and Sacrifice, London 1953, 82.

18. Gen. 24:27; 32:11; 47:29; Eks. 34:6; Jos. 2:14; Deut. 7:9; 2 Sam. 2:6; 7:15-16; 15:20; Hos. 4:1; Miga 7:20; Ps. 25:10; 26:3; 31:24; 36:6; 40:11,12; 57:4,11; 61:8; $69: 14 ; 85: 11 ; 86: 15 ; 88: 12 ; 89: 2,3,15,25,29,34,50 ; 92: 3 ; 98: 3 ; 100: 5 ; 115: 1 ; 117: 2$; 138:2; Spr 3:3; 14:22; 16:6; $20: 6,28$; Klaagl. 3:22; $3: 23$.

19. N.H. Snaith, a.w., 100. Kyk ook nota 1.

20. Agtien keer.

21. Kyk ook Hos. 4:1; Ps. 88:11; 89:2; 117:2.

22. In die verband is dit betekenisvol dat die Nuwe Afrikaanse Vertaling chéséd hier ook met 'trou' vertaal.

23. Kyk ook Ps. 132:11 en 12;

24. Meditationen über den johanneischen Begrilf der Wahrheit, Besinnung auf das Neue Testament, Exegetische Aufsătze und Vortráge II, Freiburg 1964, 272.

25. Semantics of Biblical Language, Oxford, 1961, 190v.

26. Die aanhalingstekens word gebruik om aan te dui dat daar 'n probleem bestaan oor die identiteit van die "ons" waarop daar nie in hierdie artikel ingegaan word nie.

27. So ook min of meer E Jacob, Theology of the Old Testament, London 1960, 272.

28. Kyk E Jacob, a.w., 101.

29. Kyk ook Joh. 8:17; 10:34; 12:34; 15:25.

30. TWNT IV, 878.

31. P P A Kotzé, Waarheid in die Johannesevangelie met besondere veruysing na die verbondsperspektief, ongepubliseerde doktorale proefskrif, Pretoria 1975.

32. Die interessante vraag hoekom die skrywer juis ook gebruik gemaak het van begrippe en motiewe wat so bekend was in die Hellenistiese denkwêreld soos Logos en die dualisme: Bo en onder, waarheid en leuen, lig en duisternis, ens., val buite die bestek van hierdie artikel. 